\title{
基于离子尺寸与孔径关系的不对称电容行为
}

\author{
孙刚伟宋文华刘小军乔文明凌立成* \\ (华东理工大学化学工程联合国家重点实验室, 上海 200237)
}

\begin{abstract}
摘要: 采用具有不同孔径分布的活性炭作为电极材料, 研究了离子尺寸与孔结构对电容性能的影响. 结果表 明, 正负极表现出不对称的电容行为, 正负极的质量比电容分别为 113 和 $7 \mathrm{~F} \cdot \mathrm{g}^{-1}$. 在负极电位区间, 循环伏安曲 线的响应电流明显减小. 材料表面最大电荷存储量的理论计算与实验结果有着很好的一致性, 这些结果表明用 于阳离子电荷存储的电极孔隙空间不够发达, 导致电容器在充电过程中负极材料表面达到电荷饱和状态, 进而 表现出较差的电容行为. 然而, 四氟硼酸根阴离子可以进入到正极电极材料大多数孔道中, 电极未发生电荷饱 和效应, 表现出优异的电容行为. 负极较低的比电容将会影响电容器的整体性能. 因此, 正负极应当根据离子尺 寸与电极材料孔结构的构效关系进行匹配, 以使电容器的比电容最大化.
\end{abstract}

关键词：电化学电容器；有机电解液；不对称电容行为； 孔径分布；离子尺寸 中图分类号: 0646

\section{Asymmetric Capacitance Behavior Based on the Relationship between Ion Dimension and Pore Size}

\author{
SUN Gang-Wei ～SONG Wen-Hua ～LIU Xiao-Jun ～QIAO Wen-Ming ～LING Li-Cheng* \\ (State Key Laboratory of Chemical Engineering, East China University of Science and Technology, Shanghai 200237, P. R. China)
}

\begin{abstract}
We reported on the capacitive behaviors regarding to the relationship between ion size and pore architecture, using activated carbons with an adjusted pore structure as electrode materials. The results revealed that an asymmetric capacitance response occurred in both electrodes. The gravimetric capacitances for the positive and negative electrodes were 113 and $7 \mathrm{~F} \cdot \mathrm{g}^{-1}$, respectively. A significant current decay was presented in the negative region of cyclic voltammetry curve. Experimental and calculated maximum storage charges had a good agreement. This results suggested that the insufficiently developed pore architecture for cation accommodation led to a saturation effect on the active surface, consequently, a deteriorated capacitive performance in the negative electrode. Contrarily, when pore size was larger than tetrafluoroborate dimension, the saturation effect was not found. However, this was at the expense of the lower specific area capacitance in the positive electrode. The poor capacitive behavior of the negative electrode would limit the usable voltage of the cell system and consequently the deliverable energy and power. As a result, an optimal match between the pores size and the ion dimension with respect to each electrode would be considered to obtain the maximum capacitance for the capacitor unit.
\end{abstract}

Key Words: Electrochemical capacitor; Organic electrolyte; Asymmetric capacitance behavior; Pore size distribution; Ion dimension

Received: October 15, 2010; Revised: November 19, 2010; Published on Web: December 21, 2010.

"Corresponding author. Email: lchling@ecust.edu.cn; Tel: +86-21-64252924; Fax: 86-21-64252914.

The project was supported by the National Natural Science Foundation of China (50730003).

国家自然科学基金重点项目(50730003)资助

C Editorial office of Acta Physico-Chimica Sinica 


\section{Introduction}

Electrochemical capacitors (ECs) are extensively studied due to their promising properties in terms of energy storage and power supply, which could fill the gap between the secondary batteries and the conventional dielectric capacitors. ${ }^{1,2}$ Today's major research efforts focus on increasing the deliverable energy of ECs, which is still lower than that achievable with batteries. The energy $E$ is defined by the relationship

$$
E=0.5 C U^{2}
$$

where $C$ and $U$ are the capacitance and voltage, respectively. Energy improvements require increasing both capacitance and voltage..$^{3-6}$

Presently, organic-based industrial systems are preferred, operating at a maximum voltage of $2.7 \mathrm{~V}$ as compared to $1 \mathrm{~V}$ for aqueous ones. ${ }^{7,8}$ A good matching between the pore size of electrode material and ion dimension of electrolyte is critical for an optimal capacitance. ${ }^{9-11}$ A noticeable increase in specific capacitance has recently been demonstrated for pore size of less than $1 \mathrm{~nm}$, with maximum for an average pore size of $0.7 \mathrm{~nm}$. This suggested that solvated ions were capable of at least partially removing their solvent shell to enter such small pores, consequently, leading to a higher capacitance. ${ }^{12-17}$ Due to the difference in sizes of cation and anion adsorbed at the negative and positive electrodes, respectively, a deep study should be carried out to study the capacitance behaviors of each electrode separately during the charge/discharge of ECs. Below, an asymmetric capacitive property between two electrodes can be observed where a decay of capacitive current occurs in the negative electrode as charging processes. This phenomenon highlights the need to adapt the nanotextural properties of each electrode to size of specific ions for maximizing the capacitance and thus the energy density.

\section{Materials and methods}

\subsection{Preparation and characterization of the electrode materials}

Three nanoporous activated carbons from petroleum coke

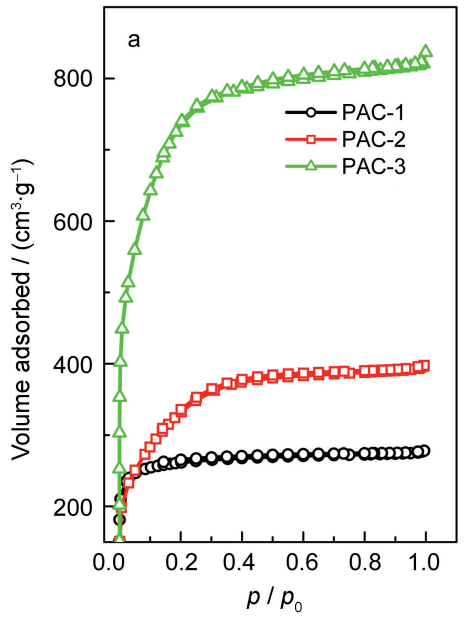

were produced by $\mathrm{KOH}$ (purity $>88 \%$ ) activation (mass ratio of $\mathrm{KOH}$ to coke from $1: 1$ to $3: 1,800{ }^{\circ} \mathrm{C}, 1 \mathrm{~h}$ ). The as-prepared activated carbons were labeled as PAC-1, PAC-2, and PAC-3, where number represents the mass ratio of $\mathrm{KOH}$ to coke. The porosity was investigated by nitrogen adsorption at $77 \mathrm{~K}$ (Micromeritcs ASAP2020, USA). Preliminarily, the samples were outgassed for $12 \mathrm{~h}$ at $300{ }^{\circ} \mathrm{C}$. The Brunauer-Emmett-Teller (BET) method was utilized to calculate the specific surface area. The pore size distribution was evaluated according to the density functional theory (DFT) approach. ${ }^{18}$

\subsection{Electrochemical measurements}

Electrodes were prepared by mixing as-prepared specimen (85\%, mass fraction, the same below) with carbon black (5\%, Mitsubishi Chemical, Inc.) and polytetrafluoroethlyene (10\%, Mitsui Dupont Fluorochemicals, Inc.). Electrochemical experiments were carried out with Teflon Swagelok ${ }^{\circledR}$ type two-electrode configuration, which was constructed with two identical carbon pellets, sandwiched with a porous polymeric separator (Celgard, USA). A silver wire $(2 \mathrm{~mm}$ ) placed between the electrodes acted as quasi-reference electrode. It was assumed that the concentration of silver ions at the silver electrode did not change during cycling, and therefore, potential remained constant. Electrolyte was $1.0 \mathrm{~mol} \cdot \mathrm{L}^{-1}$ solution of terabutylammonium terafluoroborate $\left(\mathrm{Bu}_{4} \mathrm{NBF}_{4}\right.$, Sigma-Aldrich, CAS \#429-42$5, \mathrm{H}_{2} \mathrm{O}<10 \times 10^{-6}$, purity $>99.99 \%$ ) in propylene carbonate (PC, Sigma-Aldrich, CAS \#108-32-7). Galvanostatic charge-discharge tests were conducted to calculate the specific capacitance using an Arbin SCTS supercapacitor testing system (Arbin instrument, TN, USA). Cyclic voltammetry (CV) was recorded in a potential range of -1.2 to $0 \mathrm{~V}$ and 0 to $1.2 \mathrm{~V}$ on a PCI4/300 potentiostat (Gamry, PA, USA).

\section{Results and discussion}

Fig.1 $(a, b)$ represent the $\mathrm{N}_{2}$ adsorption-desorption isotherms and the pore size distributions of three carbon samples, respectively. The increased nitrogen adsorbed volume with the mass ratio of $\mathrm{KOH}$ to coke increasing suggests a rising specific sur-

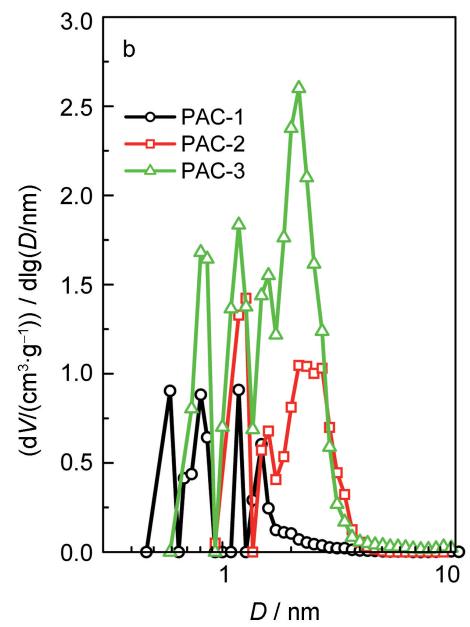

Fig.1 $\mathrm{N}_{2}$ adsorption-desorption isotherms (a) and pore size distributions calculated with DFT model (b) for all samples 
Table 1 Porosity parameters of activated carbon samples

\begin{tabular}{cccccccc}
\hline Sample & $S_{\text {BEI }} /\left(\mathrm{m}^{2} \cdot \mathrm{g}^{-1}\right)^{\mathrm{a}}$ & $S_{\text {DFI }}\left(\mathrm{m}^{2} \cdot \mathrm{g}^{-1}\right)^{\mathrm{b}}$ & $S_{\text {DFF }}(0.83-1.66) /\left(\mathrm{m}^{2} \cdot \mathrm{g}^{-1}\right)^{\mathrm{c}}$ & $S_{\text {DFT }}(>1.66) /\left(\mathrm{m}^{2} \cdot \mathrm{g}^{-1}\right)^{\mathrm{d}}$ & $S_{\text {DFT }}(0.48-0.96) /\left(\mathrm{m}^{2} \cdot \mathrm{g}^{-1}\right)^{\mathrm{e}}$ & $S_{\text {DFT }}(>0.96) /\left(\mathrm{m}^{2} \cdot \mathrm{g}^{-1}\right)^{\mathrm{f}}$ & $V_{V} /\left(\mathrm{cm}^{3} \cdot \mathrm{g}^{-1}\right)^{8}$ \\
\hline PAC-1 & 797 & 1001 & 108 & 16 & 878 & 124 & 0.36 \\
PAC-2 & 1099 & 526 & 216 & 196 & 118 & 408 & 0.44 \\
PAC-3 & 2277 & 1693 & 517 & 386 & 790 & 903 & 1.09 \\
\hline
\end{tabular}

${ }^{\mathrm{a}}$ SSA calculated using BET model; ${ }^{\mathrm{b}} \mathrm{SSA}$ calculated using DFT approach; ${ }^{\mathrm{c}}$ DFT surface area related with pore sizes between $0.83 \mathrm{to} 1.66 \mathrm{~nm}$; ${ }^{\mathrm{d}}$ DFT surface area related with pores larger than $1.66 \mathrm{~nm} ;{ }^{\circ}$ DFT surface area related with pore sizes between 0.48 to $0.96 \mathrm{~nm}$;

${ }^{\mathrm{f}} \mathrm{DFT}$ surface area related with pores larger than $0.96 \mathrm{~nm} ;{ }^{\mathrm{g}}$ total pore volume calculated at the $p / p_{0}=0.985$

face area (SSA) from PAC-1 to PAC-3. PAC-1 is strictly ultramicroporous, i.e., in the range of the recommended size of 0.84 $\mathrm{nm}$ for the $\mathrm{Bu}_{4} \mathrm{~N}^{+}$cation, whereas PAC-2 presents substantial amount of mesopores $(>2 \mathrm{~nm})$, in addition to large micropores $(>1 \mathrm{~nm})$. For PAC-3, a broad pore size distribution in the range of 0.5 to $4 \mathrm{~nm}$ can be observed. Table 1 summarizes the porosity parameters of activated carbon samples. The difference in absolute values between $S_{\mathrm{BET}}$ and $S_{\mathrm{DFT}}$ is expected as both types of calculations are based on different assumptions, which might not be justified with the utmost accuracy for all samples under study. It is well established that BET model gives adequate accurate SSA for mesoporous materials, it may not be accurate when micropores $(<1-2 \mathrm{~nm})$ are present, while DFT model is better for calculation of SSA of most micropores. ${ }^{19,20}$ PAC-1 has somewhat lower $S_{\mathrm{BET}}$ than PAC-2; whereas, $S_{\mathrm{DFT}}$ for PAC-1 is higher than that of the latter, which is associated with their difference in the terms of pore dimension and distribution. It is necessary to note that the surface functionality generated by activation does not impact the capacitance behaviors in non-aqueous electrolyte. ${ }^{21}$ The electrochemical results will depend exclusively on the effect of porosity.
The dimensions of cation and anion are evaluated using a computer model (MS Modeling v 3.2.0.0) which is a modified version of the Allinger's MM2 force field. ${ }^{22}$ For the organic electrolyte solution, the computed value accounts for the nonsolvated state of the ions specie, given that the number of solvent molecules (salvation shell) is unknown. Based on energy optimization, terabutylammonium cation $\left(\mathrm{Bu}_{4} \mathrm{~N}^{+}\right)$has a shape far from spherical-like geometry as presented in Fig.2. Therefore, we select a representative value for ion size according to the van der Waals volume. The radii for $\mathrm{Bu}_{4} \mathrm{~N}^{+}$and $\mathrm{BF}_{4}^{-}$are 0.42 and $0.24 \mathrm{~nm}$, respectively, which is in good agreement with value reported in literature. ${ }^{23}$

For corroborating ion accessibility during the capacitor operation, the potential range of each individual electrode (positive and negative) versus quasi-reference electrode is recorded while charging-discharging the capacitor is up to a given voltage, as depicted in Fig.3. A close look at Fig.3a reveals a nonlinear shape of the "potential-time" curve in the negative electrode. This is not a resistively related effect due to a low current density of $100 \mathrm{~mA} \cdot \mathrm{g}^{-1}$. By contrast, in the case of the positive electrode, a well-defined linear shape of discharge curve

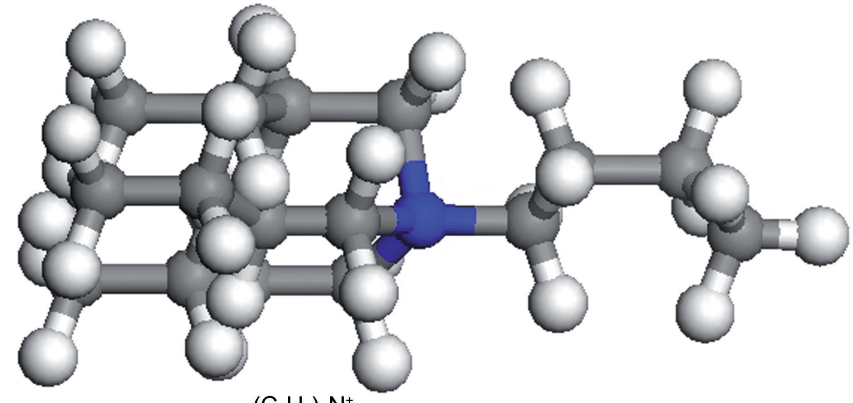

$\left(\mathrm{C}_{4} \mathrm{H}_{9}\right)_{4} \mathrm{~N}^{+}$

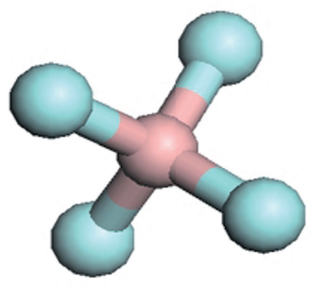

$\mathrm{BF}_{4}^{-}$

Fig.2 Ball-stick models of $\mathrm{Bu}_{4} \mathrm{~N}^{+}$and $\mathrm{BF}_{4}^{-}$with constrained geometry

The models are oriented in a way to demonstrate the close value of ions thickness.
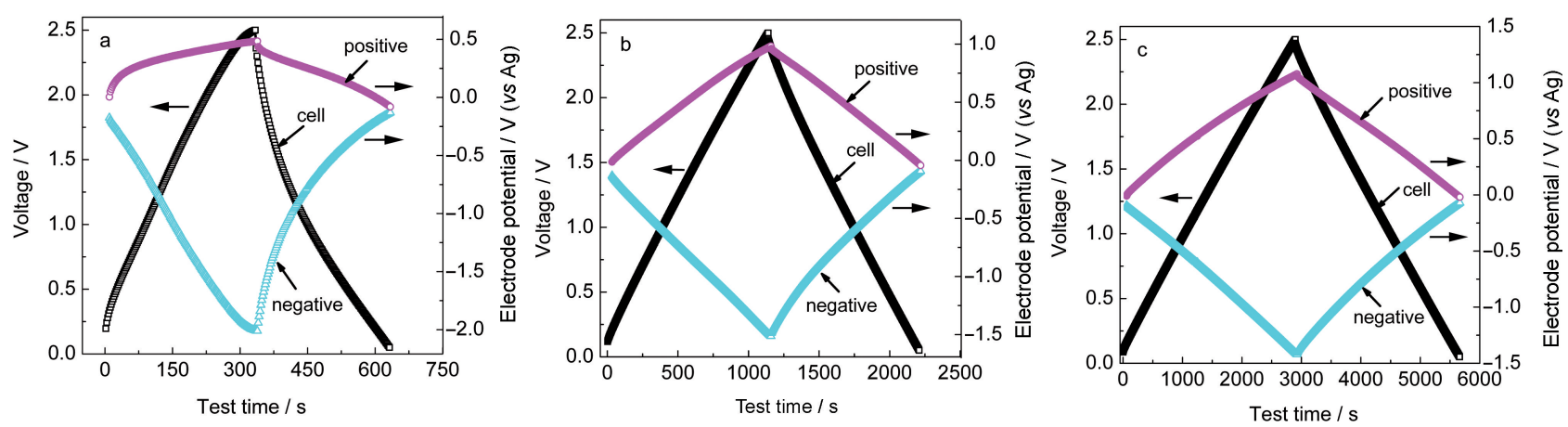

Fig.3 Potential profiles of the positive and negative electrodes during galvanostatic charge/discharge for samples of

PAC-1 (a), PAC-2 (b), and PAC-3 (c) 

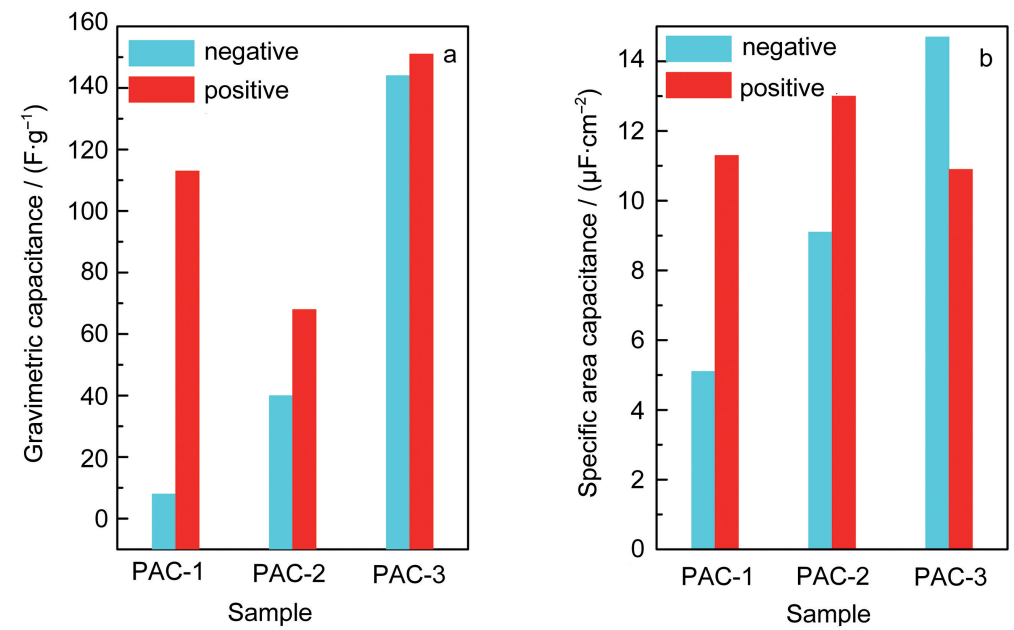

Fig.4 Comparisons of gravimetric capacitances (a) and specific area capacitances (b) between the positive and negative electrodes at $0.1 \mathrm{~A} \cdot \mathrm{g}^{-1}$

can be observed. In addition, the potential range of the positive electrode $\left(\Delta E^{+}\right)$is smaller than that of negative one $\left(\Delta E^{-}\right)$. For a symmetric capacitor with two electrodes having the same mass, this indicates that the capacitance given by the positive electrode is larger than that of negative one. As opposed to those of PAC-1, capacitance behaviors between the positive and negative electrodes with respect to the PAC-2 and PAC-3 become nearly equal (shown in Fig. $3 b$ and 3c). Based on aforementioned analysis, it is reasonable to ascribe such asymmetric capacitance behavior of PAC-1 into a narrow pore distribution of small size.

Fig.4a compares the gravimetric capacitances given by the positive with those given by the negative. PAC-1 provides significantly higher capacitance value in the positive electrode than that in the negative one, which are 113 and $7 \mathrm{~F} \cdot \mathrm{g}^{-1}$, respectively. However, the nearly identical gravimetric capacitances of each electrode can be obtained for PAC-3. As observed from Fig.4b, difference in specific area capacitances of both electrodes is not as obvious as gravimetric capacitance for PAC-1. Amazingly, in the case of PAC-3, specific area capacitance of negative is superior to that of positive electrode. The detailed explanation will be presented later.

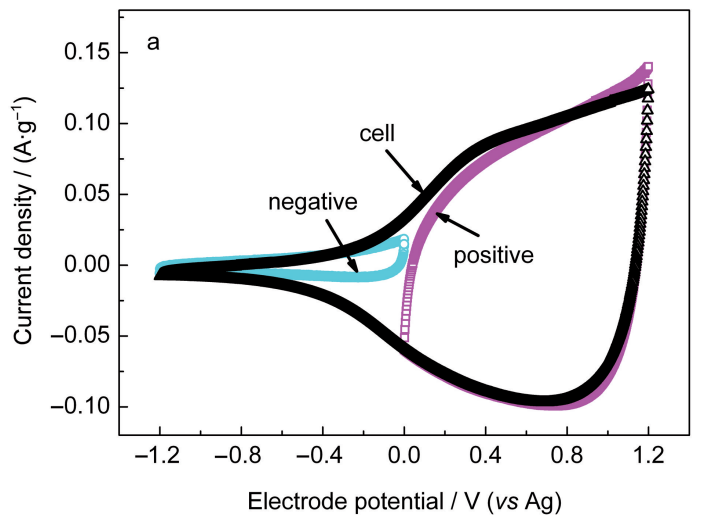

Fig.5a shows the CV curves of PAC-1 from open-circuit potential (OCP) down to negative potential $(-1.2 \mathrm{~V} v s$ reference electrode) and from OCP up to the positive potential $(1.2 \mathrm{~V} v \mathrm{~s}$ reference electrode) at a voltage scan rate of $2 \mathrm{mV} \cdot \mathrm{s}^{-1}$. As the potential scan range is higher than OCP (electrodes are kept positively charged during the whole scan), the capacitance behavior is originated from adsorption/desorption of anions, i.e., $\mathrm{BF}_{4}{ }^{-}$; when potential range is lower than OCP (electrodes are kept negatively charged during the whole scan), the capacitance property reflects adsorption/desorption of cations, i.e., $\mathrm{Et}_{4} \mathrm{~N}^{+}$. A remarkable feature of the CV curves for PAC-1 is that capacitive current of the negative electrode is greatly diminished during charging processes as compared to that of the positive one, which is in good agreement with results from galvanostatics tests. This effect negatively affects the deliverable energy because the overall capacitance is limited by the electrode with poor capacitive behavior.

Such a current decay in the negative electrode could arise from the salt depletion, referred to as the "electrolyte starvation" effect. ${ }^{24,25}$ This explanation does not sound satisfactory if applied to our case because $1 \mathrm{~mol} \cdot \mathrm{L}^{-1}$ electrolyte is more concentrated than the solutions usually exhibiting the starvation ef-

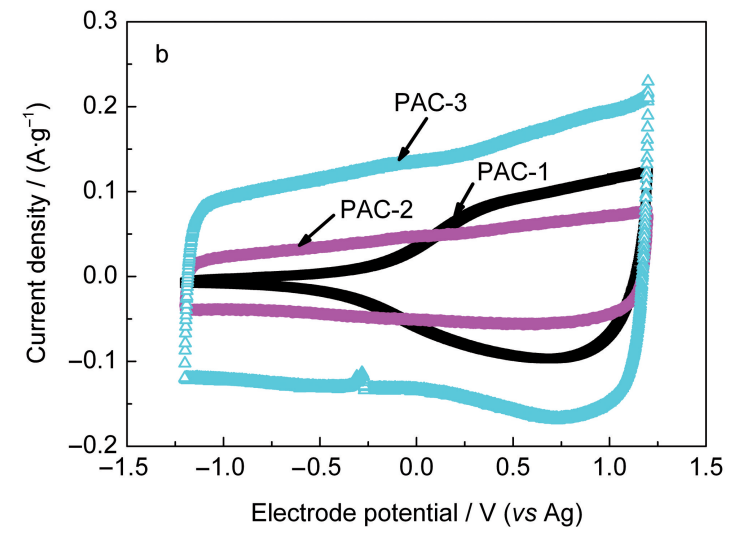

Fig.5 Comparisons of $\mathrm{CV}$ curves between positive and negative electrodes for PAC-1 (a) and CV curves in the potential range from -1.2 to $1.2 \mathrm{~V}$ ( $\mathrm{vs} \mathrm{Ag}$ ) for all samples (b) at a scan rate of $2 \mathrm{mV} \cdot \mathrm{s}^{-1}$ 
Table 2 Experimental and calculated charge values of each electrode for PAC-1

\begin{tabular}{ccccccc}
\hline Ion species & $R / \mathrm{nm}^{\mathrm{a}}$ & $S_{\mathrm{a} 1} /\left(\mathrm{m}^{2} \cdot \mathrm{g}^{-1}\right)$ & $S_{\mathrm{a} 2} /\left(\mathrm{m}^{2} \cdot \mathrm{g}^{-1}\right)$ & $Q_{\max } /\left(\mathrm{C} \cdot \mathrm{g}^{-1}\right)^{\mathrm{b}}$ & $Q_{\text {exp }} /\left(\mathrm{C} \cdot \mathrm{g}^{-1}\right)^{\mathrm{c}}$ & $Q_{\text {cell }} /\left(\mathrm{C} \cdot \mathrm{g}^{-1}\right)^{\mathrm{d}}$ \\
\hline$\left[\left(\mathrm{C}_{4} \mathrm{H}_{9}\right) \mathrm{N}\right]^{+}$ & 0.42 & 108 & 16 & 20.6 & 22.7 & 770.6 \\
{$\left[\mathrm{BF}_{4}\right]^{-}$} & 0.24 & 878 & 124 & 542.0 & 90.5 \\
\hline
\end{tabular}

${ }^{\text {a }}$ ions radius according to the van der Waals volume; ${ }^{b}$ the values of $Q_{\max }$ are calculated according to ion dimensions and surface area of electrode accessible to electrolyte ions; ${ }^{\text {th }}$ the values of $Q_{\text {exp }}$ are given for the experiment at a scan rate of $2 \mathrm{mV} \cdot \mathrm{s}^{-1}$; ${ }^{\text {d }}$ the values of $Q_{\text {cell }}$ are total available charges in the EC unit on account of the electrolyte used.

fect. What's more, if this is the case, both the positive and negative electrodes should demonstrate the same starvation effect. To state definitively whether the current decrease in the negative regions can be linked to electrolyte shortage or not, one should make a comparison between the amount of charge available in the cell $\left(Q_{\text {cell }}\right)$ and the amount of experimentally stored charge $\left(Q_{\text {exp }}\right)$. The amount of stored charge $Q_{\text {exp }}$ can be established from the Eq.(2):

$$
Q_{\exp }=\int i_{\mathrm{dl}} \mathrm{d} t
$$

where $i_{\mathrm{dl}}$ is the response current with the integration limits over the time of scan between $-1.2-0 \mathrm{~V}$ ( or $0-1.2 \mathrm{~V}$ ). Table 2 presents data on the charge stored in the experiment, $Q_{\text {exp }}$ for the negative electrode is $22.7 \mathrm{C} \cdot \mathrm{g}^{-1}$. On the other hand, the total available anionic charge can be calculated to be $Q_{\text {cell }}=770.6 \mathrm{C}$. $\mathrm{g}^{-1}$ on account of the amount of electrolyte used, its concentration, and the electrode mass. The $Q_{\text {cell }}$ is one order of magnitude larger than $Q_{\text {exp. }}$. Thus it seems unlikely that "electrolyte starvation" causes a significant current decay in the negative potential.

Herein, a novel explanation is proposed that the accessible surface area with respect to each electrode is different, determined by the ion dimension. Taking into account the porosity data obtained from gas adsorption on PAC-1, it appears that bulky $\mathrm{Bu}_{4} \mathrm{~N}^{+}$cation cannot accommodate its size so as to enter into the ultramicropores of carbon, leading to the electrode surface saturation in the negative electrode. However, given the small size of the counteranion, it can access to pores of smaller sizes. Such reasoning can be verified through comparing maximum storage charge $\left(Q_{\max }\right)$ with the experimental one, according to the pore structure of electrode material and desolvated ion dimension of salt. The $Q_{\max }$ of electrode material can be calculated using the SSA (available from DFT data), which is accessible to electrolyte ions. For the negative electrode, the maximum number of $\mathrm{Bu}_{4} \mathrm{~N}^{+}$cations $(0.84 \mathrm{~nm})$ can be evaluated by dividing the SSA into two regions: (i) the region of a single cation-layer between the pore walls, with corresponding surface area $S_{\text {a1 }}$ (the surface area relating to the pore size between 0.83 and $1.66 \mathrm{~nm}$ ) and (ii) the region of a double cations-layer between pore walls, with corresponding surface area $S_{\mathrm{a} 2}$ (the surface area of pores over $1.66 \mathrm{~nm}){ }^{26}$ It is considered that surface area per cation is equal to the surface area of a circle of radius. The number of cations on this surface is $1.3 \times 10^{20}$ ions $\cdot \mathrm{g}^{-1}$, which translates into the maximum charge, $Q_{\max }=20.6 \mathrm{C} \cdot \mathrm{g}^{-1}$. This value is in good match with $Q_{\text {exp }}, 22.7 \mathrm{C} \cdot \mathrm{g}^{-1}$. Therefore, the decay of capacitive current in the negative electrode can really be associated with the complete coverage of the electrode surface by cations. The slight discrepancies between $Q_{\text {exp }}$ and $Q_{\max }$ can point to the uncertainties of cation size and ion distortion, which permits the cation to enter pores smaller than its rigid size.

Contrarily to the negative electrode, no saturation feature is observed from $\mathrm{CV}$ curve in the positive electrode which can be corroborated by calculations (as done for the negative electrode). The experimentally stored charge for the positive electrode, $Q_{\text {exp }}=90.5 \mathrm{C} \cdot \mathrm{g}^{-1}$, is lower than the maximum charge for electrode material, $Q_{\max }=542.0 \mathrm{C} \cdot \mathrm{g}^{-1}$ as listed in Table 2 . As a consequence, the saturation effect of electrode surface area would not occur in the positive potential range.

The effect of pore size distribution on capacitance behaviors of both electrodes can be further clarified by introducing samples of PAC-2 and PAC-3. The nearly rectangular shape of CV curves for these two carbons demonstrates that the differences in pore texture among three samples are of prime influence on surface saturation in the negative electrode as revealed from Fig.5b. Using the same calculation method as the one detailed above, the fact of $Q_{\max }>Q_{\text {exp }}$ (not shown here) for each electrode is agreement with the shape of the experimental voltammograms in the case of PAC-2 and PAC-3. Notably, although PAC-2 has the lower $S_{\mathrm{DFT}}$ than PAC-1, symmetric CV curves can be obtained as compared to that of PAC-1, which is indicative of the importance for matching between electrode pore size and ion dimension. For the larger ion dimension than pore size, ions are not able to sufficiently distort for adjusting its dimensions to the pore sizes, and only a fraction of the porosity is accessible to the electrolyte ions. In this situation, the capacitive current decay would be take place without regarding to the SSA of electrode material.

On the other hand, as observed from Fig.4b, the specific area capacitances in the positive electrode experience slight decrease with the pore size increasing. In the case of PAC-3, above $99 \%$ of the overall porosity is accessible for the $\mathrm{BF}_{4}^{-}$anion (above $0.48 \mathrm{~nm}$ ) as compared to $53 \%$ for the $\mathrm{Bu}_{4} \mathrm{~N}^{+}$cation (above $0.83 \mathrm{~nm}$ ), whereas specific area capacitance of the positive electrode is lower than that of the negative one. Such behaviors could be understood as a consequence of the difference in pore-ion interaction. The distance $(d)$ between the pores surface and the ions is larger for the anion than for cation. Thus the specific area capacitance would be smaller for the positive electrode according to the Eq.(3):

$$
C_{\mathrm{S}}=\varepsilon / d
$$

where $C_{\mathrm{s}}$ represents the specific area capacitance, $\varepsilon$ is the dielectric constant (permittivity) of the electrolyte, and $d$ is the 
charge separation. It appears that pores are too wider for an effective interaction of anions with pore walls. Therefore, a large fraction of the pore volume is underused. ${ }^{27}$ It is necessary to point out that too narrow pore size would lead to the surface saturation; whereas, too wide pore dimension would decrease the utilization efficiency of electrode materials. Both situations would deteriorate the capacitance properties. Therefore, the optimal match between the pore size and the ion dimension with respect to each electrode should be considered for the maximum capacitance value of the capacitor unit.

\section{Conclusions}

In summary, for some nanoporous activated carbons, an asymmetric capacitance response can be observed between the positive electrode and negative one. The gravimetric capacitance of the positive electrode is significantly higher than that of the negative one. The disproportional match between pores size and $\mathrm{Bu}_{4} \mathrm{~N}^{+}$dimension would lead to porosity saturation in the negative electrode. This can be explained by the fact that bulky cation is unable to accommodate its size so as to enter in the narrow micropores of activated carbon. On the contrary, there is no saturation phenomena observed in the positive electrode due to the mostly pores remarkable higher than the anion size. The values of maximum storage charge are in good agreement with the experimentally measured ones, which further clarify the effect of pore architecture on the charge storage effectiveness. However, too wide pore size for ion accommodation would also have detrimental impact on the capacitance performance due to the weak pore-ion interaction. The inferior capacitance value in the negative electrode would limit the overall performance of the electrochemical capacitor unit. The different matching requirements between porosity characteristics and ionic type related to the asymmetric capacitance behaviors should be considered in order to optimize the electrochemical performance.

\section{References}

(1) Winter, M.; Brodd, R. J. Chem. Rev. 2004, 104, 4245.

(2) Chen, H. S.; Cong, T. N.; Yang, W.; Tan, C. Q.; Li, Y. L.; Ding, Y. L. Prog. Nat. Sci. 2009, 19, 291.

(3) Wang, D. W.; Li, F.; Liu, M.; Lu, G. Q.; Cheng, H. M. Angew. Chem. Int. Edit. 2008, 47, 373.

(4) Frackowia, E. Phys. Chem. Chem. Phys. 2007, 9, 1774.

(5) Pandolfo, A. G.; Hollenkamp, A. F. J. Power Sources 2006, 157,
11.

(6) Liu, B.; Shioyama, H.; Akita, T.; Xu, Q. J. Am. Chem. Soc. 2008, 130, 5390.

(7) Korenblit, Y.; Rose, M.; Kockrick, E.; Borchardt, L.; Kvit, A.; Kaskel, S.; Yushin, G. ACS Nano 2010, 4, 1337.

(8) Janes, A.; Lust, E. J. Electrochem. Soc. 2006, 153, A113.

(9) Largeot, C.; Portet, C.; Chmiola, J.; Taberna, P. L.; Gogotsi, Y.; Simon, P. J. Am. Chem. Soc. 2008, 130, 2730.

(10) Chmiola, J.; Largeot, C.; Taberna, P. L.; Simon, P.; Gogotsi, Y. Angew. Chem. Int. Edit. 2008, 47, 3392.

(11) Lin, R.; Taberna, P. L.; Chmiola, J.; Guay, D.; Gogotsi, Y.; Simon, P. J. Electrochem. Soc. 2009, 156, A7.

(12) Gogotsi, Y.; Nikitin, A.; Ye, H.; Zhou, W.; Fischer, J. E.; Yi, B.; Foley, H. C.; Barsoum, M. W. Nat. Mater. 2003, 2, 591.

(13) Shanina, B. D.; Konchits, A. A.; Kolesnik, S. P.; Veynger, A. I.; Danishevskii, A. M.; Popov, V. V.; Gordeev, S. K. Carbon 2003, 41, 3027.

(14) Permann, L.; Latt, M.; Leis, J.; Arulepp, M. Electrochim. Acta 2006, 51, 1274.

(15) Dash, R.; Chmiola, J.; Yushin, G.; Gogotsi, Y.; Laudisio, G.; Singer, J.; Fischer, J.; Kucheyev, S. Carbon 2006, 44, 2489.

(16) Fernandez, J. A.; Arulepp, M.; Leis, J.; Stoeckli, F.; Centeno, T. A. Electrochim. Acta 2008, 53, 7111.

(17) Latt, M.; Kaarik, M.; Permann, L.; Kuura, H.; Arulepp, M.; Leis, J. J. Solid State Electrochem. 2010, 14, 543.

(18) Ravikovitch, P. I.; Neimark, A. V. Langmuir 2006, 22, 11171.

(19) King, K. S. W.; Everett, D. H. Pure Appl. Chem. 1985, 57, 603.

(20) Ravikovitch, P. L.; Neimark, A. V. Colloids Surf. A 2001, 187-188, 11 .

(21) Hulicova-Jurcakova, D.; Seredych, M.; Lu, G. Q.; Bandosz, T. J. Adv. Funct. Mater. 2008, 18, 1.

(22) Brunauer, B.; Deming, L. S.; Deming, W. E.; Teller, E. J. Am. Chem. Soc. 1940, 62, 1723.

(23) Ue, M. J. Electrochem. Soc. 1994, 141, 3336.

(24) Pell, W. G.; Conway, B. E.; Marincic, N. J. Electroanal. Chem. 2000, 491, 9 .

(25) Zheng, P. L.; Jow, T. R. J. Electrochem. Soc. 1997, 144, 2417.

(26) Mysyk, R.; Raymundo-Pinero, E.; Pernak, J.; Beguin, F. J. Phys. Chem. C 2009, 113, 13443.

(27) Ania, C. O.; Pernak, J.; Stefaniak, F.; Raymundo-Pinero, E.; Beguin, F. Carbon 2009, 47, 3158. 